\title{
Big Cabinets, Big Governments? Grand Coalitions and Public Policy in the German Laender
}

\author{
ALINE SCHNIEWIND, MARKUS FREITAG Politics and \\ Management, University of Konstanz \\ ADRIAN VATTER Institute of Political Science, University of Berne
}

\begin{abstract}
The inauguration of Germany's grand coalition of Christian Democrats (CDU/CSU) and the Social Democrats (SPD) raises questions about the public policy performance of a coalition of ideological opposite. This paper turns attention to influence of coalition governments on the size of government in the German Laender from 1992 to 2005. We investigate whether grand coalitions at the sub-national level in Germany systematically affect government spending for education (including cultural affairs) and internal security. The article argues that the effects of grand coalitions on the size of the public sector are moderated by partisan politics but sometimes in unexpected ways. For example, government spending in the field of education is reduced when leftist parties are powerful in the Laender.
\end{abstract}

Key words: coalitions, public expenditure, consensus democracy, size of government

\section{Introduction}

According to partisan theory, the ideological positioning of the incumbent government affects the direction of public policy (Hibbs I977; Schmidt I996). However, what are the consequences of a government which comprises the two major national parties, representing policy goals both of the left and of the right? Neo-liberals often fear a surge in state activity, as each of the two major parties try to satisfy the demands of their own electorates, thereby causing government spending to skyrocket under a grand coalition. Because they are more inclusive, grand coalitions as special forms of consensual governments are said to spend more on public policy. In contrast to majority governments, which are defined as one party majority executives as well as minimal winning coalitions, consensual governments generally comprise grand and oversized coalitions as well as 
minority governments (de Winter 2005; Lijphart 1999). Their aim is thus to accommodate the demands of as many voters as possible (e.g., Crepaz i996a, b; 2002; Lijphart ı999; Tavits 2004).

A grand coalition consisting of the two major German parties - the Christian Democrats (CDU/CSU) and the Social Democrats (SPD) was formed in 2005 to head the parliament. Germany had only once before seen such a constellation of parties hold office after World War II - namely, from ig66 to I969. For this reason, both political scientists and the politically interested public are rather unsettled by the public policy consequences of such an unlikely form of government in Germany.

This paper sheds empirical light on the impact of coalition governments by examining the influence of coalition governments on the size of the public sector in the German context by evaluating the situation in the Laender from 1992 to 2005. In doing so, we investigate whether grand coalitions, i.e., CDU/CSU and SPD coalitions, at the sub-national level are systematically related to the degree of state intervention in the fields of education policy and internal security in Germany. We also evaluate whether the effects of grand coalitions on the size of government are moderated by partisan politics. We concentrate on government expenditure for education and internal security policies because according to the Basic Constitutional Law of the Federal Republic of Germany (Basic Law, Art. 70 ff.), the Laender are granted ample room for maneuver in these policy areas. Unlike at the national level, Laender level governments have frequently been comprised of the two major parties - a further aspect which speaks to the choice of a sub-national analysis. Grand coalitions consisting of the two major parties (CDU and SPD) were in office in half of the Laender during the time period under consideration. ${ }^{\mathrm{I}}$ Particularly since the beginning of the I9gos, this type of government occurred much more frequently in the Laender than during the years following the end of the I950s (Jun 1994). From 1992 to 2005, grand coalitions as Laender executives governed in eight of the 16 states. In those states where this special kind of combination constituted the government, some of these grand coalitions were in power for over half the period of investigation. Consequently, nearly one-fifth of the governments between 1992 and 2005 were grand coalitions. The city-states of Berlin and Bremen and the Land Brandenburg experienced by far the longest era of grand coalitions during the observed time period. By contrast, grand coalitions did not constitute the executives in most of the western states - with the exception of Baden-Württemberg and recently SchleswigHolstein (since 2005) (Schniewind 2008).

Furthermore, variance between the Laender exists concerning state activities and public expenditures (Schmidt I980; Wolf/Hildebrandt 
2008). However, one major difference in governments' spending with regard to the two policies emerges: Education and cultural affairs imply much greater costs for the states' budgets than domestic security does. The states' mean expenses from 1992 to 2005 for education (including cultural affairs) are roughly five times higher than internal security spending. With regards to expenditures for education and cultural affairs during this period, major differences between the diverse sub-national units can be observed. The expenses range from about 630 Euro per capita in Rhineland-Palatinate to almost 1000 Euro per capita in Berlin and the Free State of Thuringia. Concerning the states' expenses for internal security, the numbers vary from II5 Euro per capita in North-Rhine-Westphalia to 267 Euro per capita in Berlin. $^{2}$

Moreover, the German Laender are particularly well-suited to an evaluation of the consequences of such governments in a comparative sub-national perspective (Snyder 200I, Vatter/Rüefli 2003). While they do share a general structural framework, they are nevertheless idiosyncratic enough not to be seen as a single, homogenous entity (Freitag/Vatter 2008; Snyder 200I), a characteristic that lends itself particularly well to the application of the comparative method (Lijphart I97I, 2008). Particularly in recent years, the attention paid to the German Laender has been amplified: For example, in the literature on political economy, the Laender have provided many authors with a new domain for the application of their theories and for the verification of findings of international comparative research at the sub-national level (e.g., Jochimsen/Nuscheler 2007; Galli/Rossi 2002; Schneider 2007; Seitz 2000; Wagschal I996; Wolf 2006). A forerunner is Schmidt's (I980) study on the differences between the policies of the two major parties in the Laender, wherein he finds substantial distinctions between these sub-national units concerning education and domestic security policies.

The article is structured as follows: Section 2 presents relevant theories concerning public policy and the specific aspects of consensus democracy, as well as the veto-player theory. From this theoretical background, three main hypotheses are derived. Subsequently, the methodological approach, data, and important influential factors on public policy are briefly presented in section 3. In section 4, the empirical findings are presented and discussed. Cross-sectional regression models are estimated to assess the impact of various factors on the size of government in education and internal security policies. The article closes with a conclusion in section 5 . 


\section{Grand Coalitions and Public Policy: Theories and Hypotheses}

The assumption that distinct forms of coalition governments (i.e., grand coalitions between the CDU and the SPD) act as catalysts for state intervention in the public policies of the German Laender is at the core of the present analysis. This view is supported by the key insights of the concept of consensus democracies and the veto-player theory - namely, that consensual governments or collective veto points encourage government spending (Crepaz 2002; Lijphart I999; Tsebelis 2002; Vatter/Freitag 2007).

Lijphart's (1999) famous concept of types of democracy ranges between the two ideal points of majoritarian and consensual systems, with broad and oversized multi-party coalition governments building a cornerstone of the latter. This particular characteristic of governments is the strongest element of the 'executives-parties dimension' and 'can also be seen as conceptually close to the essence of the distinction between concentration of power and the joint exercise of power' (Lijphart I999: 245). The ideal type of a consensus democracy is most suited for heterogeneous societies: Executive power is dispersed and spread over major parts of the society. It is argued that a simple 'majority rule is not only undemocratic but also dangerous' if the access to the decision-making process is continually denied to large minorities of a society (Lijphart I999: 32). Consensus democracies, with their various manifestations, are 'better at [...] representing minority groups and minority interests, representing everyone more accurately, and representing people and their interests more inclusively' (Lijphart I999: 275). In sum, the advantages of consensual political structures are that policies are more carefully deliberated, a broader spectrum of perspectives is weighed and taken into consideration, and a larger number of options are examined than in majoritarian systems (Crepaz i996a: 87-88). This amplitude of representation causes governments to be more responsive to the voters' demands. Among other things, a 'closer proximity between government policy and voters' preferences' is also said to be a characteristic of consensus democracies (Lijphart i999: 293). This should lead to an expansion of governments' role in society because the needs of a greater proportion of the population have to be met (Tavits 2004). Consequently, the size of government should increase (Tavits 2004). Moreover, Crepaz (I996b: 9) classifies multiparty governments with high popular support as 'encompassing organizations' in terms of Mancur Olson (I986). He states that 'the more encompassing parties become, the more their interest and the 'general interest' converge; thus they tend to behave more responsibly by minimizing redistributive policies favoring particular groups' (Crepaz I996b: 9). For the reasons stated above, Lijphart (I999: 294) again, 
points out that consensual democracies are associated with 'kinder, gentler and more generous policies.'

With regard to the veto player theory, it is argued that the greater the number of veto players, the more difficult it is to change the status quo, thereby limiting the capacity of state expansion (Tsebelis 2002). However, according to Crepaz (2001, 2002: 173) and Wagschal (1999a), there are different kinds of veto players with contradictory effects on policy outcomes. As far as competitive veto points - separate agencies with mutual veto powers, as in federalism and direct democracy - are concerned, one would indeed expect them to restrain government (Obinger I998; Vatter/Freitag 2007). Here, political power is diffused by means of institutional separation and mutual veto power leading to deadlock and restrictive effects. By contrast, collective veto points, such as parliaments, interest groups, or parties in a coalition's government favor 'policies with expansionary consequences', as the resistance to cutbacks 'is certainly more expedient politically' (Crepaz 2002: I73-4). Political power is dispersed within these collective veto points where responsibility is shared within a single body. This leads to extended negotiation and logrolling, which is expected to have an expansive effect on government expenditure. In this regard, parties in a coalition's government share collective authority and interact with one another on a face-to-face-basis without the protection of separate institutions with mutual veto powers. Within partisan veto players, there is an inherent bias of all coalition partners with regards to expansionary policies through logrolling. While the parties must interact with one another on an ongoing basis, they nevertheless have distinctive constituencies with distinctive preferences. Overall, coalition governments have a reduced capacity to exercise restraint in government expenditures. Against this background, Persson et al. (2003) find that coalition governments generally spend more than one party governments. Rising government expenses are shown to be positively associated with an increasing number of governing parties (Crepaz 2002) as well as with an increasing number of parties in national legislatures (Mukherjee 2003). This congruence of the concepts of collective veto players, encompassing organizations, and consensus democracy allows us to formulate the following main hypothesis:

Hypothesis I: Multi-party coalition governments enhance government spending:

Where grand coalitions more frequently control the Laender executives, the governments in these Laender are larger.

In addition, we expect the influence of grand coalitions on the size of government to be strengthened by partisan politics reflecting the political-ideological center of the respective coalition. The hypothesis of partisan influence on public policy, the 'parties-do-matter' view, is a 
stylized empirical theory of a democratic political market (Schmidt I996). According to this approach, a major determinant of variation in policy choices and policy outputs in democracies is the strength of left, center, or liberal parties (Hibbs I977; Schmidt 1996). Therefore, coalition governments do not automatically perform as transmission belts between private desires and public policy; a more active interest representation and articulation is needed. Parties are however capable of carrying out such an active articulation and representation (Tavits 2004: 353). In other words, the impact of consensual institutions on the size of government is contingent upon partisan influences on public policy, and vice versa. Concerning education policy, for example, leftist parties generally tend to prefer social equality and promote a stronger public sector in education (e.g., Boix I997; Schmidt 2002; Tufte 1978). Social democratic or socialist parties are therefore expected to attach greater importance to the equality of educational opportunities - this should manifest itself in higher education expenditures during left-party led governments. If one expects that consensual governments execute major state expenses because 'such systems provide better opportunities for the lower social strata to be represented in government, then this effect should be reinforced in the event of large leftist-party share of cabinet seats, provided that people from the lower social strata or interests advocating more government involvement in economy and society comprise, for a large part, the constituency of the leftist parties' (Tavits 2004: 353). Furthermore, for right and center leaning parties, the field of internal security is a matter of particular importance (Norris 2007). These parties are therefore expected to enlarge state activity in this policy field.

Against this background, we hypothesize that the claimed expansionary effect of grand coalitions varies with the degree of participation by leftist or rightist parties in the decision making process. Concerning security policy, we expect that growing strength of rightist parties results in even higher spending in the field of internal security policy; whereas strong left parties should lead to increases in education spending. In terms of the German Laender, Wolf (2006: I23ff.) argues in favor of a more explicit partisan effect on government expenditure in the sub-national units; the maneuverability is greater in the Laender because there are fewer veto players than at the national level. The evidence, however, is ambiguous; some authors find affirmation of the partisan hypothesis in certain policies: Schmidt (1980) reports higher expenditures in education and internal security policy during social democratic governments; some report higher spending by left-oriented executives in labor policy (Schmid/Blancke 2006; Schmid/Hedrich 2008). Other authors do not however find support for the partisan 
influence on state expenditures in general (Seitz 2000) or on education expenditures in particular (Wolf 2005; Zohlnhöfer 2007). Galli and Rossi (2002: 298) find that rightist governments spend more, as measured by total expenditures. To some extent, their results support the hypothesis that leftist governments 'are inclined to spend more on education and health; rightist governments on administration.' ${ }^{\text {'3 }}$ These findings lead us to the next working hypotheses:

Hypothesis 2a: Grand coalitions tend to spend more on internal security policies when rightist parties are stronger.

Hypothesis 2b: Grand coalitions tend to spend more on education policies when leftist parties are stronger.

\section{Research Design, Method, and Data}

For the remainder of this paper, our primary focus will be on testing the hypotheses presented above. The influence of grand coalitions on government spending will be analyzed for the period from 1992 to 2005. We chose 1992 as our starting point because this was the first year with complete data available for all Laender. There was a certain time period at the beginning of the I99os where not all indicators were homogenized for all German Laender. Moreover, more recent data have not yet been made available by the German Federal Statistical Office. For several reasons, the limits inherent to this time period do not seem to be problematic: First, with a period covering I4 years, three to five governments per state are included in the analysis. Second, the 'old' Federal Republic of Germany must be differentiated from the 'new' Federal Republic of Germany. Reunification has brought about countless changes: Not only has the number of states grown from i to i6, but the relationships between the states and to the federal government have also been altered to some extent. ${ }^{4}$ Third, Laenderlevel grand coalitions have been on the rise since I990. Between 1972 and I99I, for example, no grand coalitions between the CDU and the SPD occurred in any state. Finally, the analysis of a time period that is close to the present one allows one to draw conclusions about the current state politics.

Our investigation is based on an analysis of the influence of grand coalitions on the size of government in the 16 German Laender. To test the assumed relationships, multiple cross-sectional OLS regressions are conducted by incorporating several control variables into the models. The rationale for including these factors is as follows: '[E]ven where institutional arrangements do contribute to overall differences in specific capabilities, moreover, these effects usually are strongly mediated by other institutional and non-institutional factors' (Weaver/ 
Rockman I993: 446). For each variable, the mean for the years I992-2005 was calculated. ${ }^{5}$ In other words, the multivariate crosssectional analyses are obtained by averaging the values of the individual variables. ${ }^{6}$

Our dependent variable is the size of government and is measured by two indicators: total public expenditure of the Laender for internal security and for education (and cultural affairs). Both are measured in euros per capita and adjusted for price. The main independent variable is the mean proportion of time grand coalitions governed in the Laender executives during the years 1992 to 2005. Based on established theories of state expenditure in cross-national comparative policy research, a number of other control variables are included in the model. ${ }^{7}$ Subsequently, the resulting control hypotheses derived from the relevant literature on policy analysis and political economy used to assess the impact of grand coalitions on government spending are discussed. One major and well-established hypothesis in the comparative policy research is the partisan approach, which states that left-wing parties generally tend to spend more than right-wing parties (i.e., Blais et al. 1993; Boix 1997; Bräuninger 2002, 2005; Cusack 1997; Cusack/ Fuchs 2003; Hibbs I977, I992; Hicks/Swank I992; Jochimsen/ Nuscheler 2007; Mukherjee 2003; Schmidt i996; Zohlnhöfer 2001). ${ }^{8}$ The strength of both right and left parties is measured as the respective proportion of seats these parties hold in the Laender parliaments.

An important variable comes from the socio-economic determination hypothesis (e.g., Schmidt I996): It is assumed that economic prosperity leads to new challenges for the state as well as a new set of societal problems to tackle, thereby leading to higher government spending. Therefore, the gross domestic product per capita (adjusted for price) is included in the analysis. Finally, a dummy variable is included in the analysis to control for the considerable differences that continue to persist between the old and the new Laender (e.g., Schmid/Blancke 2006; Schmid/Hedrich 2008; Wolf 2006). A brief overview of all variables, their measurements, and the expected relationships can be found in the appendix.

\section{Empirical Findings}

This section analyzes the impact of grand coalitions on the size of government in the German Laender between 1992 and 2005. Multiple regression models were estimated to evaluate the influence of the different factors discussed. For each of the four models, the means of the different variables were used for the regression equation. ${ }^{9}$ Table I reports the empirical findings. 
Table I. Determinants of Public Sector Size in German Laender, means I992-2005

\begin{tabular}{|c|c|c|c|c|}
\hline Variable/Model & Model I & Model 2 & Model 3 & Model 4 \\
\hline Dependent variable & \multicolumn{2}{|c|}{$\begin{array}{c}\text { Internal security expenditure per } \\
\text { capita }\end{array}$} & \multicolumn{2}{|c|}{$\begin{array}{l}\text { Education expenditure per } \\
\text { capita }\end{array}$} \\
\hline Constant & 8г.o6 & 88.46 & 479.43 & 440.33 \\
\hline Grand coalition & $0.62 * *(3.06)$ & $0.70^{* *}(3.07)$ & $0.49 * *(2.30)$ & $0.94^{* * *}(4.66)$ \\
\hline Strength of rightist parties & - & $-0.22(-\mathrm{I} . \mathrm{IO})$ & - & - \\
\hline $\begin{array}{l}\text { Interaction grand coalition } \\
\text { and strength of rightist parties }\end{array}$ & - & $0.33(\mathrm{I} .54)$ & - & - \\
\hline Strength of left parties & - & - & - & $-0.34 *(-2.04)$ \\
\hline $\begin{array}{l}\text { Interaction grand coalition } \\
\text { and strength of left parties }\end{array}$ & - & - & - & $-0.5^{8 * *}(-3.00)$ \\
\hline $\begin{array}{l}\text { Gross domestic product per } \\
\text { capita }\end{array}$ & $0.47(\mathrm{I} .60)$ & $0.45(1.67)$ & $0.64 *(2.07)$ & $0.77 * * *(3 \cdot 35)$ \\
\hline East-West-Dummy & $0.06(0.20)$ & $0.09\left(0.3^{2}\right)$ & $0.49\left(\mathrm{I} .5^{6}\right)$ & $0.65^{* *(2.79)}$ \\
\hline F-Test & $4 \cdot 4^{2 * *}$ & $4.03 * *$ & $3 \cdot 49^{* *}$ & $6.42 * * *$ \\
\hline Number of observations & I6 & I6 & I6 & I6 \\
\hline Adjusted $\mathrm{R}^{2}$ & $0.4 \mathrm{I}$ & 0.50 & 0.33 & 0.64 \\
\hline
\end{tabular}

Notes: OLS regressions, standardized coefficients. Values of the t-statistic in parentheses. $*=$ significant at the Io per cent level (two-tailed test), $* *=$ significant at the 5 per cent level (two-tailed test), $* * *=$ significant at the $\mathrm{I}$ per cent level (two-tailed test); see text and appendix for the operationalizations and data sources. All key financial data (domestic security expenditure per capita, education expenditure per capita, and gross domestic product per capita) are price-adjusted values (source: Federal Statistical Office).

With regard to models I and 2, which display the results of the determinants of public spending on internal security, up to 50 per cent of the variance in the dependent variable expenditure can be explained. Additionally, the hypothesized positive effect of grand coalitions on domestic security expenses is confirmed: The more frequently grand coalitions as special forms of consensual governments represent the Laender executives during the period from 1992 to 2005 , the higher the public expenditures are for internal security. However, the effect of grand coalitions on the size of government is not moderated by partisan politics. The empirical analyses do not reveal any partisan influence of rightist parties on this policy. All other factors appear to be of minor importance: Neither economic prosperity nor the difference between the old and the new Laender are systematically related to the public expenditure for internal security. The results do however warrant further testing. As we are dealing with a very small number of cases, individual units (in this case, Laender) can quickly exert a large influence on the estimation of the parameters. Given these 
circumstances, we have performed a variety of regression diagnostics in order to test for robustness of the above findings.

The estimated regression models do not suffer from heteroscedasticity and therefore the standard errors did not need to be corrected. Furthermore, tests for multicollinearity revealed no critical results. A number of additional regression methods have been applied to assess the robustness of the results. An analysis of outliers and influential cases was also performed. The value of the Breusch-Pagan test for heteroscedasticity is not significant and well below the critical value; all values of the variance inflation factor are well below the critical value of io (Schnell I994). Lastly, robust regression methods (such as median regression, robust regression, and regression with robust standard errors) were also conducted.

The identification of influential cases (or outliers) was carried out graphically via the inspection of the leverage vs. squared-residuals plot, as well as formally by inspecting the values of Cook's Distance (values higher than I $(4 / \mathrm{n})$ constitute influential cases; Kohler/Kreuter 200I). These tests lead us to question the robustness of the estimations. For example, model 2, which examines the impact of grand coalitions and rightist parties on governments' expenditure on internal security, is very sensitive to the inclusion of one specific Land. Grand coalition thus loses its significance when Berlin is excluded from the analysis. Additionally, the coefficient of the interaction effect changes its sign and shows a negative influence. It appears that the relationship between the independent and the dependent variable is produced solely by the influence of the Land Berlin. Compared to the other Laender, Berlin constitutes a special and exceptional case for several reasons. Not only is Berlin the federal capital of Germany and is faced with major liabilities in terms of protecting foreign embassies and most of the federal state authorities, it is also a melting pot of cultures, as it is the only federal state that was itself reunited with unification. While we can control for East or West German history in the other Laender, we cannot do so for Berlin. It therefore should not come as much of a surprise that Berlin exerts such a strong influence on the analysis of the determinants of Laender security spending. Therefore, further interpretation of the model and an investigation of the (insignificant) marginal effect of grand coalitions will not be carried out.

When looking at models 3 and 4 , the results of the multivariate analyses can be summarized as follows: First, and most notably, grand coalitions have a positive influence on education expenditure: Where grand coalitions as special forms of consensual governments were more frequent in the Laender executives between 1992 and 2005, education expenditures were also higher. Second, with regard to the partisan 
variable, it should be noted that the strength of left parties is significantly related to the size of government in education policy. The effect however contradicts the findings of international comparative studies and supports the results of Wolf (2006) in his analyses of educational policy in Germany: The stronger left-oriented parties are, the less a government spends for education. ${ }^{\text {IO }}$ How is this finding to be explained? In general, social democrats in Germany attach great importance to the field of vocational training, which is mainly financed by private companies (Wolf 2006). ${ }^{\text {II }}$ This should benefit their electorate more than investments in the very costly sector of higher education. Furthermore, Alber (I986) argues that, in general, the German labor movement has historically regarded education as subordinate topic. This disregard is explained by the fact that the (Prussian) state attended to the matter of education relatively early (Alber ig86; Wolf 2006). These circumstances may be responsible for the unexpected negative influence of stronger left parties on education expenditure. Third, the coefficient of the interaction effect has a negative sign and is significant at the five per cent level (Table I). There is thus a multiplicative effect between grand coalitions and left parties on education expenditure. When left parties within grand coalitions are weaker, higher government spending for education and cultural affairs can be observed. If left parties possess medium or low strength (i.e., less than about 59 per cent), a significant marginal effect of grand coalitions on education expenditure arises. Of the i 6 states, roughly 80 per cent are marked by a significant variation in education expenditure that is contingent upon the strength of left parties. Fourth, the coefficients of the control variables are both significant: Economic prosperity leads to increased expenditure for education policy and the new Laender also spend more in this field. Finally, it can be reported that model 4 is capable of explaining roughly 64 per cent of the variance in government spending on education.

The estimated regression models 3 and 4 suffer neither from the problem of heteroscedasticity nor multicollinearity. The value of the Breusch-Pagan test for heteroscedasticity is not significant and below the critical value. The values of the variance inflation factor are well below the critical value of io (Schnell i994: 247). Additional regression methods have been applied to assess the robustness of the results. ${ }^{12}$ Further analysis yielded outliers and influential cases: The exclusion of the three most problematic cases (Baden-Württemberg and Berlin, identified via a leverage vs. squared-residuals plot, and Hamburg, additionally identified via the inspection of the values of Cook's Distance) does not change the sign of the estimated coefficients and the coefficients of the three main variables of interest remain significant. It 
should also be noted that the reported findings are not sensitive to the random inclusion of other controlling factors such as the proportion of Catholics as a socio-cultural factor (Castles I989, I994; Hega I999; Schmidt 2002, 2004), voter turnout (Cusack/Fuchs 2003; Tavits 2004), level of debt (Wolf 2006), the degree of dependence on international trade (Cameron 1978; Cusack/Fuchs 2003; Garrett/Mitchell 2001; Scharpf I999; Tavits 2004), and - specific to the German Laender the balance of the Fiscal Equalisation System (Wolf 2006). ${ }^{13}$

\section{Conclusion}

This article finds that grand coalitions differ in their influence on public expenditure according to policy domains and partisan politics. However, in contrast to our theoretical expectations, stronger left parties in the Laender lead to lower expenses for education policy and cultural affairs (see also, Wolf 2006). In contrast to their international counterparts, the German left parties do not invest significantly more in education than the Christian Democrats or the Liberals. Social democratic parties and labour unions are advocates of in-plant training (Thelen 2004: 4I) as part of Germany's dual system of vocational training. Their constituencies include youths in low social strata who benefit particularly from this popular alternative to university studies. As regards vocational training, a large part of spending is done by private companies. This is supported by the finding of Stern (2000) that expenses for schools (per pupil) are higher in SPD-governed Laender but expenses for universities (per student) are considerably higher in CDU-governed Laender (Hetmeier/Weiß 2001: 39; Klemm 2003).

What are the implications of our empirical findings for other federal systems, where education is typically devolved? In the United States, the phenomenon of divided government may be considered as an alternative form of grand coalition,. Empirical research on divided government (Alesina/Rosenthal 1995; Alt/Lowry 1994; Fiorina 1996) has found evidence that in divided governments with competing parties whose core constituents have different preferences which can be addressed through public spending there tends to be more spending on public policy in general and on education in particular than in unified governments. The distinctive objectives of the different parties who control the executive and legislative branches of government, coupled with the uncertainty about the outcome of the next election, seem to foster public growth. Our findings are also in line with recent research on Switzerland, another federal country with a very decentralised education system. Freitag/Bühlmann's (2003) study of public education 
expenditure in Swiss cantons shows that educational expenditure is systematically related to the cabinet type and the number of parties in cantonal government: the more encompassing the grand coalition government in a Swiss canton, the higher the spending for public education.

Some authors argue that minority governments resemble grand coalitions very closely (Lijphart I999; Strøm I984, I990). Usually, minority coalitions need to find additional legislative support through bargaining as the case arises. Therefore, those minority governments which are very common for example in Scandinavia should perform similarly to the grand coalitions analyzed in this paper.

Can linkages between the sub-national and the national levels be made based on the present findings? Downs (I998: 244), for example, suggests that national elites have the opportunity to learn from the experimentation at sub-national levels. According to our findings, it remains unclear whether the current grand federal coalition should be more conducive to the growth of the public sector. There are two obstacles to the expansion of the public sector at the federal level. First, with regard to education policy, the strength of the SPD within the coalition should not encourage government expenditure. Second, compared to the Laender, the room for maneuver at the federal level is constrained because there are more veto players than at the sub-national level (Wolf 2006: I23ff.), such as an independent central bank, bicameralism, a powerful constitutional court and the diffusion of federal political power imposing mutual vetoes. Thus, as Schmidt (1996: I74) has argued the Federal Republic of Germany can be regarded as a grand coalition governed by a formal or informal grand coalition of the major established parties and a formal or hidden grand coalition of federal government and state governments.

\section{Acknowledgement}

This article was written as part of a research project on patterns of democracy in the German Laender which was funded by the German Research Foundation. We would like to thank Birgit Jacob, Jennifer Shore, the anonymous reviewers and the editor for their valuable comments on previous drafts. 


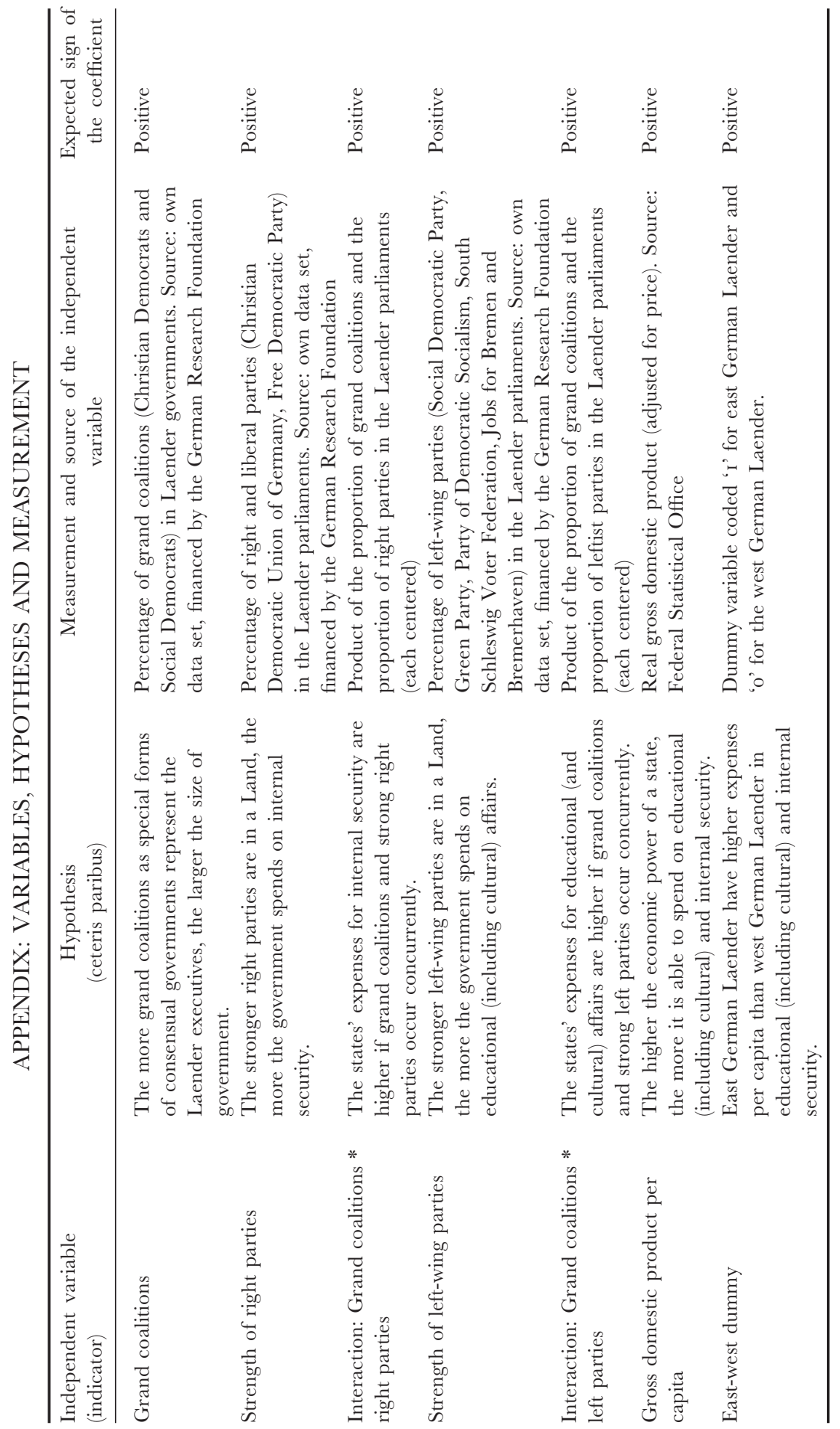




\section{NOTES}

I. In Bavaria, a sister party of the CDU (Christian Democratic Union), the CSU (Christian Social Union), exists. As the CSU fills the role of the CDU in Bavaria, the CDU does not participate in elections. The platforms of the CDU and the CSU are very similar and the two parties work together in a parliamentary group at the federal level. Therefore, we will not further differentiate between the two and will refer to both parties as the CDU (Jochimsen/Nuscheler 2007: 5-6; for a discussion of the treatment of 'closely allied parties,' see Lijphart ig99: 69ff.).

2. The classification of various budget items differs between the Laender (e.g., Schmid/Hedrich 2008). To avoid discrepancies and to establish comparability, public spending for the fields of education (and cultural affairs) and internal security on this relatively high level have been aggregated. Additionally, for the city-states Berlin, Bremen, and Hamburg, there is no clear separation between the budgets at the state and the local levels; all revenues and expenses are reported conjointly. To remedy this situation and to render the states' budgets comparable, adjustments to the city-states' expenses at the local level were conducted. In this vein, we follow Wolf (2006) and calculate the proportion of local investments to the total expenses at state and local levels in the area states (Flächenländer). Based on these computations, the fraction of the investments at the local level was estimated and subtracted from the total expenses of the city-states. The basis for this estimation are the western area states (concerning the expenses of the city-states Bremen and Hamburg), and all non city-states (concerning Berlin's expenditures).

3. The literature is similarly ambiguous with regards to investigations of political economy such as deficit policy in the German Laender: Whereas Seitz (2000) and Jochimsen/Nuscheler (2007) find no party effect, Schneider (2007) and Wagschal (I996: 225 and 23I) find higher deficits in SPD-governed Laender.

4. In Germany, there exists a so-called 'Federal Financial Equalisation System' between the Federal Government and the Laender (Federal Ministry of Finance: 2007; Basic Law of the FRG, Article 107). Within this system, a financial equalization takes place among the Laender. Additionally, there is the possibility for poorer Laender to receive supplementary federal grants. As of 1995, the new Laender have also participated in this Federal Financial Equalisation System, which implied major changes for the old Laender. All new Laender are net recipients. Some of the old Laender altered from net recipients to net contributors. Those Laender that continued to be net recipients sustained dramatic losses in their revenues from the Equalisation System (Federal Ministry of Finance: 2007; own calculations).

5. If a change of the orientation of governments between grand coalitions and other forms of cabinet occurred during a given year, this year was assigned the new property. If repeated changes in a government's orientation have taken place during a given year, the mean of the corresponding values was calculated. As only minor changes have occurred and an overall mean was computed, this proceeding does not seem to be problematic.

6. We have consciously decided against using a pooled time-series cross-sectional analysis because exactly those variables that we are interested in (the type of government and composition of the parliament) remain constant over several years. The estimate of the effects of variables that scarcely vary over time would therefore be distorted by a time-series cross-sectional design.

7. Unfortunately, with only i 6 units of analysis, the model may contain only a few variables. The maximum number of variables included in the equation is five, when all states are included. The minimum number of degrees of freedom that has to be maintained is ro (Wagschal r999b: 234).

8. These two values are virtually interchangeable as the Pearson correlation coefficient for the proportions of the two party families is negative and highly significant $(r=-0.97, p<0.00 \mathrm{I})$. Furthermore, the strength of right and/or left parties is also included for technical reasons: Since we estimate the influence of a multiplicative interaction effect between the proportion of grand coalitions and the strength of right and/or left parties, the two components of this product must be included in the model for each case (Brambor et al. 2006; Jaccard/Turrisi 2003).

9. To estimate the possible influence of the interaction effect between the proportion of grand coalitions and the partisan variable, the respective variables were centered and the product of the centered variables was calculated for each case.

Io. If the proportion of left-wing members in government is used alternatively, the results are nearly the same, although the problem of multicollinearity arises. Furthermore, the two indicators are highly correlated (Pearsons coefficient of correlation $r=0.78, p<0.00 I$ ) and can therefore be used as substitutes. 
II. Private investments are made by churches, charities, and private households. In sum, about one-third of all investments in the field of education are made by private institutions, although the assignment to the particular areas remains difficult, if not impossible (Hetmeier/Weiß 200r: 39; Klemm 2003).

I2. Robust regression methods (such as median regression, robust regression, and regression with robust standard errors) were conducted. Some of the coefficients were not significant for all models; however, the signs of the coefficients remain the same for all methods applied. As Jann (2006) argues, this speaks to the validity of findings, particularly when examining small to very small samples.

I3. As a further test of the robustness of the results, we calculated the model with an alternative dependent variable: When education spending is measured in proportion to a state's total spending, the three main variables of interest do not change in sign and remain significant at least at the ten per cent level.

\section{REFERENCES}

Alber Jens (I986): Germany. Pp. I-I54 in Flora Peter (Ed.), Growth to Limits. The Western European Welfare States Since World War II. Volume 2: Germany, United Kingdom, Ireland, Italy. Berlin: De Gruyter.

Alesina Roberto and Rosenthal Howard (i995): Partisan Politics, Divided Government, and the Economy. Cambridge: University Press.

Alt James E. and Lowry Robert C. (I994): Divided Government, Fiscal Institutions, and Budget Deficits: Evidence from the States. American Political Science Review 88: 81 I-828.

Blais André, Donald Blake and Dion Stéphane (I993): Do Parties Make a Difference? Parties and the Size of Government in Liberal Democracies. American Fournal of Political Science 37: 40-62.

Boix Carles (I997): Political Parties and the Supply Side of the Economy: The Provision of Physical and Human Capital in Advanced Economies, I960-90. American fournal of Political Science 4I: 8I $4-845$.

Bräuninger Thomas (2005): A Partisan Model of Government Expenditure. Public Choice I25: $409-429$.

Brambor Thomas, Clark William Roberts and Golder Matt (2006): Understanding Interaction Models: Improving Empirical Analysis. Political Analysis I4: 63-82.

Cameron David (1978): The Expansion of the Public Economy: A Comparative Analysis. American Political Science Review 72: I243-I26I.

Castles Francis G. (I989): Explaining public expenditure in OECD nations. European Fournal of Political Research i7: $43^{\mathrm{I}-448 .}$

Castles Francis G. (I994): On religion and public policy: Does Catholicism make a difference? European Fournal of Political Research 25: 19-40.

Crepaz Markus M. L. (I996a): Constitutional structures and regime performance in 8 industrialized democracies: A test of Olson's hypothesis. European Fournal of Political Research 29: 87-IO4.

Crepaz Markus M. L. (I996b): Consensus Versus Majoritarian Democracy. Political Institutions and their Impact on Macroeconomic Performance and Industrial Disputes. Comparative Political Studies 29: $4^{-26}$.

Crepaz Markus M. L. (200I): Veto Players, Globalization and the Redistributive Capacity of the State: A Panel Study of I5 OECD Countries. Fournal of Public Policy 21: I-22.

Crepaz Markus M. L. (2002): Global, Constitutional, and Partisan Determinants of Redistribution in Fifteen OECD Countries. Comparative Politics 34: 169-188.

Cusack Thomas R. (I997): Partisan politics and public finance: Changes in public spending in the industrialized democracies, I955-I989. Public Choice 9I: 375-395.

Cusack Thomas R. and Fuchs Susanne (2003): Parteien, Institutionen und Staatsausgaben. Pp. 32I-354 in Obinger Herbert, Uwe Wagschal and Bernhard Kittel (Eds.), Politische Ökonomie. Opladen: Leske + Budrich.

Downs William M. (r998): Coalition Government, Subnational Style. Multiparty Politics in Europe's Regional Parliaments. Columbus: Ohio State University Press.

Federal Ministry of Finance (2007): The Federal Financial Equalisation System in Germany. URL at 00.10.2007: http://www.bundesfinanzministerium.de/cln 03/nn 4480/DE/Service/Down loads/Abt V/The 2oFederal_2oFinancial_2oEqualisation_20System_20in_2oGermany, templateld=raw,property=publicationFile.pdf

Fiorina Morris P. (I996): Divided Government. New York: Allyn \& Bacon. 
Freitag Markus and Bühlmann Marc (2003): Die Bildungsfinanzen der Schweizer Kantone. Swiss Political Science Review 9: 139-167.

Freitag Markus and Vatter Adrian (2008): Die Demokratien der deutschen Bundesländer. Politische Institutionen im Vergleich. Stuttgart: UTB.

Galli Emma and Rossi Stefania P. S. (2002): Political budget cycles: The case of the Western German Laender. Public Choice ino: 283-303.

Garrett Geoffrey and Mitchell Deborah (200I): Globalization, Government Spending and Taxation in the OECD. European Fournal of Political Research 39: 145-177.

Hega Gunther M. (1999): Consensus Democracy? Swiss Education Policy Between Federalism and Subsidiarity. New York: Peter Lang.

Hetmeier Heinz-Werner and Weiß Manfred (200I): Bildungsausgaben. Pp. 39-55 in Böttcher Wolfgang, Klaus Klemm and Thomas Rauschenbach (Eds.), Bildung und Soziales in Zahlen. Statistisches Handbuch zu Daten und Trends im Bildungsbereich. Weinheim: Juventa.

Hibbs Douglas A. (1977): Political Parties and Macroeconomic Policy. American Political Science Review 7I: $1467-$ I 487 .

Hibbs Douglas A. (1992): Partisan Theory after Fifteen Years. European Fournal of Political Economy 8: 36I-373.

Hicks Alexander M. and Swank Duane H. (1992): Politics, Institutions and Welfare Spending in Industrialized Democracies, I96o-82. American Political Science Review 86: 658-674.

Jaccard James and Turrisi Robert (2003): Interaction Effects in Multiple Regression (2nd ed). Sage University Papers Series on Quantitative Applications in the Social Sciences, o7-072. Thousand Oaks, CA: Sage.

Jann Ben (2006): Diagnostik von Regressionsschätzungen bei kleinen Stichproben, Pp. $42{ }^{2}-452$ in Diekmann Andreas (Ed.), Methoden der Sozialforschung. Sonderheft 44 der Kölner Zeitschrift für Soziologie und Sozialpsychologie. Wiesbaden: VS-Verlag.

Jochimsen Beate and Nuscheler Robert (2007): The Political Economy of the German Laender Deficits. Discussion Paper SP II 2007-o6. Berlin: Wissenschaftszentrum.

Jun Uwe (I994): Koalitionsbildung in den deutschen Bundesländern. Theoretische Betrachtungen, Dokumentation und Analyse der Koalitionsbildungen auf Länderebene seit 1949. Opladen: Leske + Budrich.

Klemm Klaus (2003): Bildungsausgaben: Woher sie kommen, wohin sie fließen. Pp. 2I $4^{-25 \mathrm{I}}$ in Cortina Kai S., Jürgen Baumert, Achim Leschinsky, Karl Ulrich Mayer and Luitgard Trommer (Eds.), Das Bildungswesen in der Bundesrepublik Deutschland. Strukturen und Entwicklungen im Überblick. Ein Bericht des Max-Planck-Instituts für Bildungsforschung. Reinbek: Rowohlt.

Kohler Ulrich and Kreuter Frauke (200I): Datenanalyse mit Stata. München: Oldenbourg.

Lijphart Arend (197I): Comparative Politics and the Comparative Method. The American Political Science Review 65: 682-693.

Lijphart Arend (1999): Patterns of Democracy. Government Forms and Performance in Thirty-Six Countries. New Haven/London: Yale University Press.

Lijphart Arend (2008): Foreword: Consensus versus Majoritarian Democracy in the German Bundesländer. Pp. 9-1o in Freitag Markus and Adrian Vatter (Eds.), Die Demokratien der deutschen Bundesländer. Politische Institutionen im Vergleich. Stuttgart: UTB.

Mukherjee Bumba (2003): Political Parties and the Size of Government in Multiparty Legislatures. Examining Cross-Country and Panel Data Evidence. Comparative Political Studies 36: 699-728.

Norris Paul (2007): Expenditure on public order and safety. Pp. I33-I58 in Castles Francis G. (Ed.), The disappearing state? Retrenchment Realities in an Age of Globalisation. Cheltenham: Edward Elgar.

Obinger Herbert (1998): Federalism, Direct Democracy, and Welfare State Development in Switzerland. Fournal of Public Policy 18: 241-263.

Olson Mancur (I986): A theory of the incentives facing political organizations: Neo-corporatism and the hegemonic state. International Political Science Review 7: 165-189.

Persson Torsten, Roland Gerard and Tabellini Guido (2003): How do electoral rules shape party structures, government coalitions, and economic policies? Working Paper. URL: http:// rincewind.iies.su.se/ perssont/papers/prt4_2Inovo3.pdf (accessed: 09.I0.2007).

Scharpf Fritz W. (I999): The Viability of Advanced Welfare States in the International Economy: Vulnerability and Options, MPIfG Working Paper 99/9. Köln: Max-Planck-Institut für Gesellschaftsforschung.

Schmid Josef and Blancke Susanne (2006): Arbeitsmarkt- und Sozialpolitik in den Bundesländern. Pp. 295-315 in Schneider Herbert and Hans-Georg Wehling (Eds.), Landespolitik in Deutschland. Grundlagen - Strukturen - Arbeitsfelder. Wiesbaden: VS Verlag. 
Schmid Josef and Hedrich Horst (2008): Arbeitslosigkeit und Arbeitsmarktpolitik in den Bundesländern: Differenzierungen und Differenzen. Pp. I93-2I4 in Wolf Frieder and Achim Hildebrandt (Eds.), Politik in den Bundesländern. Wiesbaden: VS Verlag.

Schmidt Manfred G. (1980): CDU und SPD an der Regierung. Ein Vergleich ihrer Politik in den Ländern. Frankfurt/Main: Campus.

Schmidt Manfred G. (1996): When parties matter: A review of the possibilities and limits of partisan influence on public policy. European Fournal of Political Research 30: I55-183.

Schmidt Manfred G. (2002): Warum Mittelmaß? Deutschlands Bildungsausgaben im internationalen Vergleich. Politische Vierteljahresschrift 43 (I): $3^{-19}$.

Schmidt Manfred G. (2004): Die öffentlichen und privaten Bildungsausgaben Deutschlands im internationalen Vergleich. Zeitschrift für Staats- und Europawissenschaften 2 (I): 7-3I.

Schneider Christina J. (2007): Politischer Opportunismus und Haushaltsdefizite in den westdeutschen Bundesländern. Politische Vierteljahresschrift 48: 221-242.

Schnell Rainer (1994): Graphisch gestützte Datenanalyse. München: Oldenbourg.

Schniewind Aline (2008): Regierungen. Pp. II I-I6o in Freitag Markus and Adrian Vatter (Eds.), Die Demokratien der deutschen Bundesländer. Politische Institutionen im Vergleich. Stuttgart: UTB.

Seitz Helmut (2000): Fiscal policy, deficits and politics of subnational governments: The case of the German Laender. Public Choice I02: 183-218.

Snyder Richard (200I): Scaling Down: The Sub-national Comparative Method. Studies in Comparative International Development 36: 93-110.

Stern Jutta (2000): Programme versus Pragmatik. Parteien und ihre Programme als Einfluss- und Gestaltungsgröße auf bildungspolitische Entscheidungsprozesse. Frankfurt: Peter Lang.

Strøm Kaare (1984): Minority Governments in Parliamentary Democracies. The Rationality of Nonwinning Cabinet Solutions. Comparative Political Studies 17: 199-228.

Strøm Kaare (1990): Minority Government and Majority Rule. Cambridge: University Press.

Tavits Margit (2004): The size of government in majoritarian and consensus democracies. Comparative Political Studies 37: 340-359.

Thelen Kathleen (2004): How Institutions Evolve. The Political Economy of Skills in Germany, Britain, the United States, and Japan. Cambridge: University Press.

Tsebelis George (2002): Veto Players. How Political Institutions Work. New York: Sage.

Tufte Edward R. (1978): Political Control of the Economy. Princeton: University Press.

Vatter Adrian and Rüefli Christian (2003): Do Political Factors Matter for Health Care Expenditure? A Comparative Study of Swiss Cantons. Fournal of Public Policy 23: 301-323.

Vatter Adrian and Freitag Markus (2007): The Contradictory Effects of Consensus Democracy on the Size of Government: Evidence from the Swiss Cantons. British Fournal of Political Science 37: $359-367$.

Wagschal Uwe (1996): Staatsverschuldung. Ursachen im internationalen Vergleich. Opladen: Leske + Budrich.

Wagschal Uwe (1999a): Schranken staatlicher Steuerungspolitik: Warum Steuerreformen scheitern können. Pp. 223-247 in Busch Andreas and Thomas Plümper (Eds.), Nationaler Staat und internationale Wirtschaft. Anmerkungen zum Thema Globalisierung. Baden-Baden: Nomos.

Wagschal Uwe (I999b): Statistik für Politikwissenschaftler. München: Oldenbourg.

Weaver R. Kent and Rockman Bert A. (1993): When and How Do Institutions Matter? Pp. 445-46r in Weaver R. Kent and Bert A. Rockman (Eds.), Do Institutions Matter? Government Capabilities in the United States and Abroad. Washington D.C.: The Brookings Institution.

Winter de Lieven (2005): Theoretical, Conceptual and methodological problems in applying Lijphart's Patterns of Democracy to autonomous regions in Europe. Paper presented during the Joint Sessions of the European Consortium for Political Research, Granada, April I4-I9 2005.

Wolf Frieder (2005): Die Bildungsausgaben der Bundesländer im Vergleich. Gesellschaft - Wirtschaft - Politik 54: 4II-423.

Wolf Frieder (2006): Die Bildungsausgaben der Bundesländer im Vergleich. Welche Faktoren erklären ihre beträchtliche Variation? Münster: Lit.

Wolf Frieder and Hildebrandt Achim (2008): Politik in den Bundesländern. Wiesbaden: VS Verlag.

Zohlnhöfer Reimut (200I): Parteien, Vetospieler und der Wettbewerb um Wählerstimmen. Politische Vierteljahresschrift 42: 655-682.

Zohlnhöfer Reimut (2007): Öffentliche Bildungsausgaben im inter- und intranationalen Vergleich: Machen Parteien einen Unterschied? Pp. 372-388 in Schmidt Manfred G., Tobias Ostheim, Nico A. Siegel and Reimut Zohlnhöfer (Eds.), Der Wohlfahrtsstaat. Eine Einführung in den historischen und internationalen Vergleich. Wiesbaden: VS Verlag. 
ALINE SCHNIEWIND, MA

University of Konstanz, Department of Politics and Management, Chair of Comparative Politics, PO Box 84, D-78457 Konstanz,

Germany

PROFESSOR DR MARKUS FREITAG

University of Konstanz, Department of Politics and Management, PO Box 84, D-78457 Konstanz,

Germany

PROFESSOR DR ADRIAN VATTER

University of Berne,

Institute of Political Science, Lerchenweg 36, CH-zooo Berne 9,

Switzerland 